\title{
ANALISIS ANOMALI GRAVITASI SEBAGAI ACUAN DALAM PENENTUAN STRUKTUR GEOLOGI BAWAH PERMUKAAN DAN POTENSI GEOTHERMAL (Studi Kasus Di Daerah Songgoriti Kota Batu)
}

\section{Oleh:}

\author{
Nurul Hidayat ${ }^{1}$, Abdul Basid ${ }^{2}$
}

\begin{abstract}
ABSTRAK: Telah dilakukan penelitian dengan metode gravitasi pada tanggal 26 - 27 April 2011 di daerah Songgoriti Kota Batu dengan tujuan untuk mengetahui pola anomali Bouguer dan struktur geologi bawah permukaan serta potensi panasbumi di daerah tersebut. Berdasarkan interpretasi kualitatif pada kontur anomali Bouguer lengkap didapatkan variasi nilai anomali Bouguer antara 47,3 - 67,4 mGal dengan nilai anomali tinggi terdapat pada arah tenggara penelitian dan nilai anomali sedang pada arah tenggara-selatan dan timur laut daerah penelitian. Hampir $75 \%$ daerah penelitian didominasi oleh nilai anomali Bouguer rendah. Hasil interpretasi kuantitatif pada model penampang 2D lintasan $\mathrm{AB}$ dan $\mathrm{CD}$, didapatkan tujuh lapisan batuan di bawah permukaan yaitu lapisan lapuk, tufa pasiran, anglomerat, lempung pasir, breksi tufaan terlempungkan, lava, dan breksi Vulkanik. Berdasarkan interpretasi kualitatif dan kuantitatif serta penelitian sebelumya dapat disimpulkan bahwa potensi geothermal di daerah penelitian sangat kecil.
\end{abstract}

Kata Kunci : Anomali Bouguer, Geothermal, Model Struktur Geologi.

\section{PENDAHULUAN}

Ketersediaan sumberdaya energi bahan bakar minyak bumi (BBM) akan semakin menipis seiring dengan perjalanan waktu.. Sumber daya energi yang merupakan produk sampingan dari BBM, yaitu bahan bakar gas (BBG) keberadaannya juga mengikuti BBM karena keduanya bersifat tidak dapat diperbaharui (non renewable). Oleh karena itu upaya penelitian yang berkelanjutan dalam rangka mendapatkan energi alternatif pengganti energi yang tidak terbarukan (non renewable) ini harus terus dilakukan.

Posisi Indonesia yang terletak pada pertemuan tiga lempeng (Eurasia, Hindia Australia, dan Pasifik ) menyebabkan terbentuknya deretan gunungapi di sebagian wilayah negara ini, dan menyebabkan terbentuknya sumber energi panasbumi di sekitar gunungapi tersebut. Energi panasbumi adalah energi sumberdaya alam berupa air panas atau uap yang terbentuk dalam reservoir di dalam bumi melalui pemanasan air bawah permukaan oleh batuan beku panas ${ }^{(10)}$. Energi panasbumi ini dapat dimanfaatkan secara langsung untuk pengeringan produksi hasil pertanian, pariwisata dan kebutuhan rumah tangga ataupun secara tidak langsung sebagai penggerak turbin pembangkit listrik ${ }^{(7)}$.

\footnotetext{
1,2 Jurusan Fisika Universitas Islam Negeri Maulana Malik Ibrahim Malang Koresponden penulis: El_Hidayatp6s@yahoo.co.id Created with 
Geofisika adalah ilmu yang mempelajari tentang bumi dengan menggunakan parameter-parameter fisika. Dalam hal ini yang menjadi target adalah bumi bawah permukaan. Parameter-parameter fisika yang digunakan adalah parameter mekanika yang meliputi metode seismik, gravitasi (gravity) dan magnetik. Metode gravitasi ( gravity) memiliki suatu kelebihan untuk survei awal karena dapat memberikan informasi yang cukup detail tentang struktur geologi dan kontras densitas batuan. Pada kasus panas bumi perbedaan densitas batuan merupakan acuan dalam penyelidikan metode gravitasi. Dimana, daerah sumber panas dan akumulasinya di bawah permukaan bumi dapat menyebabkan perbedaan densitas dengan massa batuan disekitarnya.

Daerah Songgoriti Batu yang terletak pada ketinggian 900-1100 meter sebelah timur laut G.Kawi-Panderman yang merupakan rangkaian gunung api padam yang termasuk dalam rangkaian gunung api Arjuno-Welirang yang masih aktif (Type B,C) meskipun tidak pernah meletus lagi. Daerah Songgoriti Batu berbatasan langsung dengan batuan basal dan andesit yang lebih tua dari G.Anjasmoro sehingga menyebabkan banyaknya terjadi kenampakan gejala pasca vulkanis di daerah ini. Penelitian sebelumnya (Priyambodo, 2004) dengan menggunakan metode Geolistrik di daerah Songoriti Batu ditemukan 8 potensi sumber air panas (hydrothermal) dan yang terbesar berada di sekitar Candi Songgoriti. Dari hasil tersebut dapat diperkirakan potensi akan energi panas bumi (geothermal) cukup besar. Hal ini diperkuat oleh laporan Subdit Panas Bumi Direktorat Vulkanologi dan Mitigasi Bencana bahwa daerah Songgoriti Batu merupakan salah satu daerah yang mempunyai potensi panas bumi (geothermal).

Penelitian ini ditujukan untuk mengetahui pola anomali Bouguer dan struktur geologi bawah permukaan di daerah Songgoriti Kota Batu serta potensi geothermal pada daerah tersebut. Dari penelitian ini diharapkan dapat memberikan memberikan informasi mengenai struktur geologi bawah permukaan dan potensi geothermal di daerah Songgoriti Kota Batu kepada pihak terkait (pengelola atau pemerintah), agar dapat memaksimalkan potensi geothermal di daerah tersebut.

\section{KAJIAN TEORI}

\section{Prinsip Gravitasi}

Teori Gravitasi didasarkan oleh hukum Newton tentang gravitasi. Hukum gravitasi Newton yang menyatakan bahwa gaya tarik menarik antara dua buah benda adalah sebanding dengan massa kedua benda tersebut dan berbanding terbalik dengan jarak kuadrat antara pusat massa kedua benda tersebut ${ }^{(4)}$.

Hukum gravitasi Newton ${ }^{(2)}$ :

$F=G \frac{m M}{F_{.}}$

Dimana, konstanta gravitasi $(\mathrm{G})=6.67 \times 10^{-11} \mathrm{~N} \cdot \mathrm{m}^{2} \cdot \mathrm{kg}^{-2}$. Sedangkan hukum Newton lainnya adalah mengenai gerak yang menyatakan bahwa gaya ( $\mathrm{F}$ ) adalah perkalian antara massa dengan percepatan. Hukum Newton mengenai gerak Newton, yaitu ${ }^{(2)}$

$$
F=m g
$$

Persamaan (1) disubstitusikan ke persamaan (2), maka didapat ${ }_{\text {Created with }}^{(2)}$ : 


$$
\mathrm{g}=G \frac{M}{R^{2}}
$$

Persaman terakhir ini menunjukkan bahwa besarnya percepatan yang disebabkan oleh gravitasi di bumi ( $g$ ) adalah berbanding lurus dengan massa bumi (M) dan berbanding terbalik dengan kuadrat jari-jari bumi (R).

Dalam metode gravitasi, pengukuran dilakukan terhadap nilai komponen vertikal dari percepatan gravitasi di suatu tempat. Namun pada kenyataannya, bentuk bumi tidak bulat sehingga terdapat variasi nilai percepatan gravitasi untuk masing-masing tempat. Hal-hal yang dapat mempengaruhi nilai percepatan gravitasi adalah perbedaan derajat garis lintang, perbedaan ketinggian (topografi), kedudukan bumi dalam tata surya, variasi rapat massa batuan di bawah permukaan bumi, perbedaan elevasi tempat pengukuran dan hal lain yang dapat memberikan kontribusi nilai gravitasi, misalnya bangunan dan lain-lain ${ }^{(8)}$.

\section{Potensial Gravitasi Distribusi Massa}

Pada potensial gravitasi berlaku prinsip superposisi yaitu potensial gravitasi dari sekumpulan massa dari masing-masing massa. Beda potensial pada partikel uji merupakan penjumlahan vektor dari potensial massa. Prinsip superposisi dapat diterapkan untuk potensial gravitasi pada distribusi massa yang kontinu. Suatu distribusi massa yang kontinu $m$ adalah sekumpulan massa yang sangat kecil dan banyak, $d m=\rho(x, y, z) d v$, dimana $\rho(x, y, z)$ adalah densitas distribusi massa. Dengan menerangakan prinsip supersposisi maka didapatkan ${ }^{(3)}$ :

$$
U(p)=\gamma \int_{v} \frac{d m}{r}=\gamma \int_{v} \frac{\rho(Q)}{r} d v
$$

Dimana pengintegralan meliputi v, volume sebenarnya dari massa. Sedangkan P merupakan titik pengamatan, $Q$ merupakan titik pengintregalan dan $r$ adalah jarak antara $P$ dan Q. Densitas memiliki satuan gr.cm ${ }^{-3(3)}$.

\section{Tinjauan Geologi Daerah Penelitian}

Daerah Songgoriti terletak di sebelah timur laut Gunung Kawi-Butak dan terletak 16 $\mathrm{km}$ sebelah barat daya rangkaian gunungapi Arjuno-Welirang. Daerah Songgoriti ini terletak kira-kira $25 \mathrm{~km}$ sebelah barat laut bagian barat dataran Malang dan termasuk daerah lembah yang banyak dikelilingi gunung. Sebelah utara berbatasan dengan Gunung Radjegwesi, Gunung Banyak, dan Gunung Kitiran. Sebelah timur berbatasan dengan Kota Batu. Sebelah selatan berbatasan dengan Gunung Bale, Gunung Kedungcangkring, dan Gunung Panderman. Sebelah barat berbatasan dengan dataran tinggi pujon ${ }^{(6)}$.

Daerah songgoriti memiliki jenis batuan gunung api Penaggungan (Qv-n) dan batuan gunung api Panderman (Qv-p) di permukaan di dominasi oleh sebaran tufa pasiran, breksi tufaan, aglomerat, lava, breksi vulkanik, dan tanah pelapukan dari breksi gunung api dan breksi tufaan umumnya lanau pasiran berkerikil dan lempung pasiran ${ }^{(6)}$. 


\title{
METODE PENELITIAN
}

\section{Waktu dan Lokasi Penelitian}

Penelitian ini dilaksakan pada tanggal 26 sampai 27 April 2011, lokasi penelitian

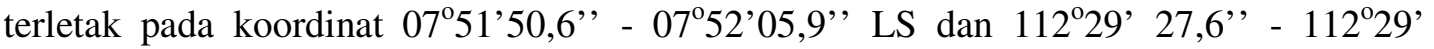
40,4' BT, disekitar sumber air panas Songgoriti, Kelurahan Songgokerto, Kecamatan Batu, Kota Batu Jawa Timur.

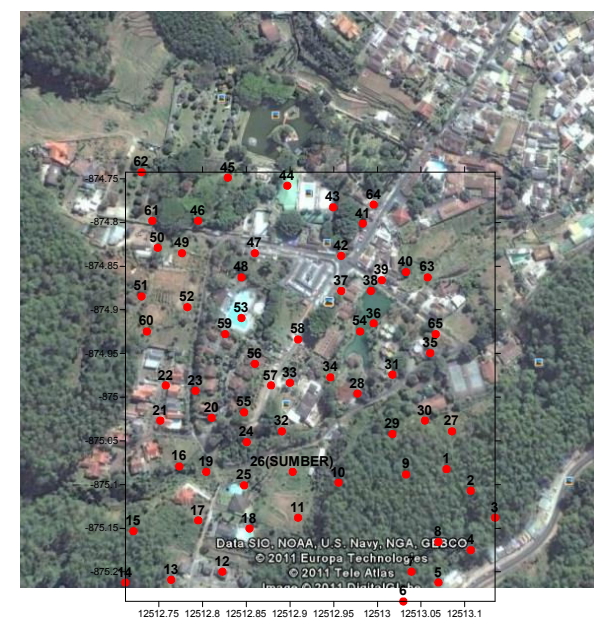

Gambar 1. Lokasi dan persebaran titik-titik penelitian

Penelitian ini meliputi tahap pengambilan (akuisisi) data, pengolahan (prosessing) data dan interpretasi terhadap hasil pengolahan data. Pada penelitian ini yang dianalisa adalah berupa data gravitasi, geologi daerah penelitian, dan kontras densitasnya.

\begin{abstract}
Akuisisi Data
Sebelum dilakukan pengambilan data, terlebih dahulu dilakukan survey lapangan, hal ini untuk memudahkan saat pengambilan data, yaitu dengan menentukan titik - titik pengukuran. Tahap selanjutnya adalah pengambilan data, yaitu dengan melakukan kalibrasi alat dan menentukan titik acuan (base station) sebelum pengambilan data di titiktitik ukur lainnya. Lokasi titik acuan harus berupa titik atau tempat yang stabil atau mudah dijangkau. Penentuan titik acuan sangat penting, karena pengambilan data lapangan harus dilakukan secara looping, yaitu dimulai dari titik acuan yang telah ditentukan, dan berakhir pada titik tersebut. Titik acuan perlu diikatkan terlebih dahulu pada titik ikat yang sudah diketahui nilai mutlaknya. Pada penelitian yang dijadikan titik acuan (base station) adalah titik ikat yang berada di Kampus Brawijaya Malang, tepatnya di belakang jurusan fisika kampus Brawijaya yang telah dikeahui nilai mutlaknya.
\end{abstract}

\section{Prosessing Data}

Pada tahap pengolahan data sering disebut dengan reduksi data gravitasi, secara umum pengolahan data gravitasi dapat dibagi menjadi dua tahapan yaitu tahap awal dan tahap lanjutan. Tahap awal meliputi seluruh proses mulai dari pembacaan nilai gravitasi sampai di dapatkan nilai anomali Bouguer di setiap titik amat. Proses tersebut meliputi,

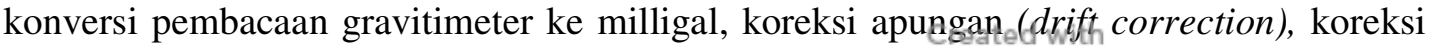


tidal (tide correction), koreksi lintang (latitude correction), koreksi udara bebas (free air Correction), koreksi Bouguer (Bouguer correction) dan koreksi medan (terrain correction). Dalam pelaksanaannya mulai dari konversi data sampai semua koreksi dapat dilakukan dengan bantuan perangkat lunak Microsoft office Excel. Sedangkan tahap selanjutnya adalah pengkonturan dan pemodelan data anomali Bouguer berdasarkan informasi nilai densitas.

\section{Interpretasi Data}

Pada prinsipnya interpretasi dapat dilakukan secara kualitatif dan kuantitatif. Interpretasi kualitatif dilakukan dengan cara membaca pola anomali gravitasi yang kemudian dihubungkan dengan tatanan geologinya dan data geologi lainnya. Sedangkan interpretasi kuantitatif dapat dilakukan dengan menganalisa penampang pola anomali sepanjang lintasan tertentu yang telah di tentukan. Dalam penelitian ini dibuat dua penampang anomali yaitu penampang $\mathrm{AB}$ dan $\mathrm{CD}$. Pada tahap interpretasi parameter benda yang diestimasi adalah posisi, dimensi, kontras rapat massa dengan sekitar, besar benda, dan lain-lain. Karena sifat ketidakunikan data gravitasi artinya benda dengan bentuk yang berlainan dapat menerangkan data yang sama, maka banyak dikembangkan berbagai metode untuk mendapatkan hasil yang optimum. Disamping itu juga diperlukan kontrol-kontrol lain misalnya data geologi, data metode geofisika yang lain.

\section{HASIL DAN PEMBAHASAN}

Pada dasarnya penyelidikan metode gravitasi adalah mencari perbedaan nilai medan gravitasi dari satu titik ke titik yang lain di suatu tempat yang disebabkan oleh distribusi massa yang terdapat di bawah permukaan daerah penelitian. Namun data yang diperoleh di lapangan merupakan hasil kompleks dari kontribusi banyak hal. Perbedaan lintang di setiap tempat, bentuk topografi bumi yang tidak datar, dan gaya tarik planet lain seperti matahri dan bulan merupakan hal-hal yang mempengaruhi nilai medan gravitasi yang disebabkan benda anomali di bawah permukaan yang sebenarnya. Oleh karena itu dilakukan pengolahan data gravitasi yang bertujuan untuk mereduksi penyebab medan gravitasi yang tidak berhubungan dengan struktur geologi penyebab anomali.

\section{Interpretasi Kualitatif}

Interpretasi kualitatif dilakukan dengan cara membaca pola anomali gravitasi Bouguer lengkap (gambar 2) yang kemudian dihubungkan dengan tatanan geologinya dan data-data kebumian lainnya sehingga secara umum dapat memberikan gambaran struktur geologi bawah permukaan daerah penelitian. Gambaran umum yang dihasilkan dari penafsiran ini hanya berupa pola-pola atau bentuk-bentuk struktur geologi tertentu saja, belum menyangkut ukuran/besaran geologi. 


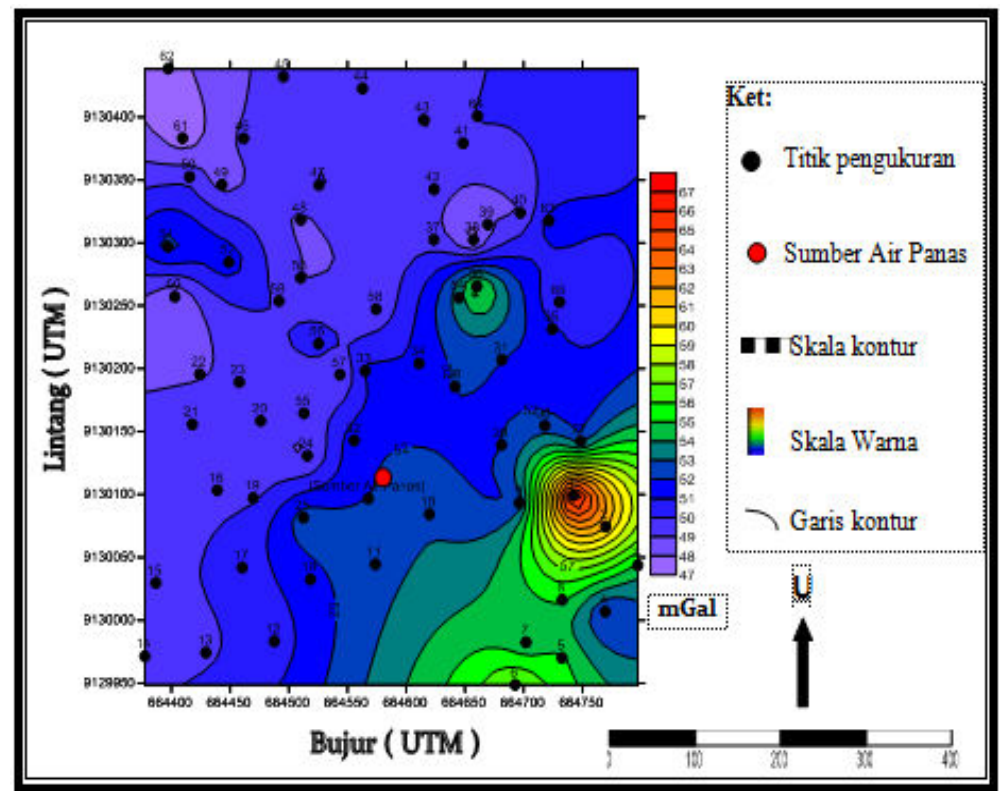

Gambar 2. Kontur anomali Bouguer lengkap

Secara kualitatif ditafsirkan bahwa pola kontur anomali Bouguer (gambar 2) dapat dibedakan menjadi 3 pola. Pola pertama adalah pola tinggian dengan rentang nilai anomali 58 - $67 \mathrm{mGal}$. Pola kedua adalah pola sedang dengan rentang anomali 53 - $57 \mathrm{mGal}$. Pola ketiga adalah pola rendahan dengan rentang nilai anomali 47 - $52 \mathrm{mGal}$. Pola tinggian berada pada arah tenggara daerah penelitian khusunya di sekitar titik 1, dengan pola klosur rapat diduga sebagai batuan beku yang cukup dangkal dengan nilai anomali antara $58-67$ mGal.

\section{Pemisahan Anomali Bouguer}

Anomali Bouguer disebabkan oleh dua bagian yaitu anomali regional (gambar 4) dan anomali lokal (gambar 5). Anomali regional bersifat smooth (halus) dan biasanya disebabkan oleh batuan-batuan yang dalam. Sedangkan anomali lokal bersifat kasar dan disebabkan oleh batuan-batuan yang dangkal. Kedua anomali tersebut harus dipisahkan karena mempunyai fungsi yang berlainan untuk mendapatkan manfaatnya secara optimum.

Pemisahan antara anomali regional dan anomali lokal bisa lakukan dengan malakukan proses kontinuasi, baik dengan kontinuasi ke atas (upward continuation) atau kontinuasi ke bawah (downward continuation), dalam hal ini penulis menggunakan proses kontinuasi keatas. Sebelum dilakukan kontinuasi perlu dilakukan reduksi ke bidang datar (gambar 3) hal ini dikarenakan data anomali Bouguer lengkap masih berada pada permukaan topografi dengan ketinggian yang bervariasi sedangkan dalam analisa lanjut diperlukan data anomali medan gaya berat yang berada pada bidang datar. Hal ini dapat diatasi dengan membawa anomali Bouguer lengkap tersebut ke bidang datar pada ketinggian tertentu menggunakan metode sumber ekivalen titik massa (Dampney, 1969) ${ }^{(9)}$. 


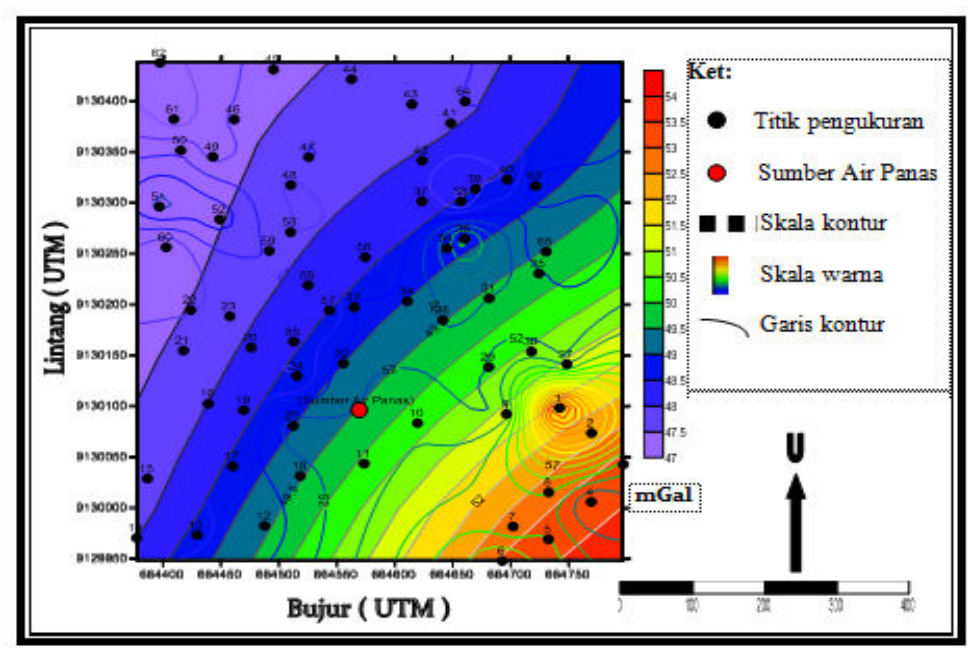

Gambar 3. Over lapping kontur hasil reduksi bidang datar dan anomali Bouguer lengkap

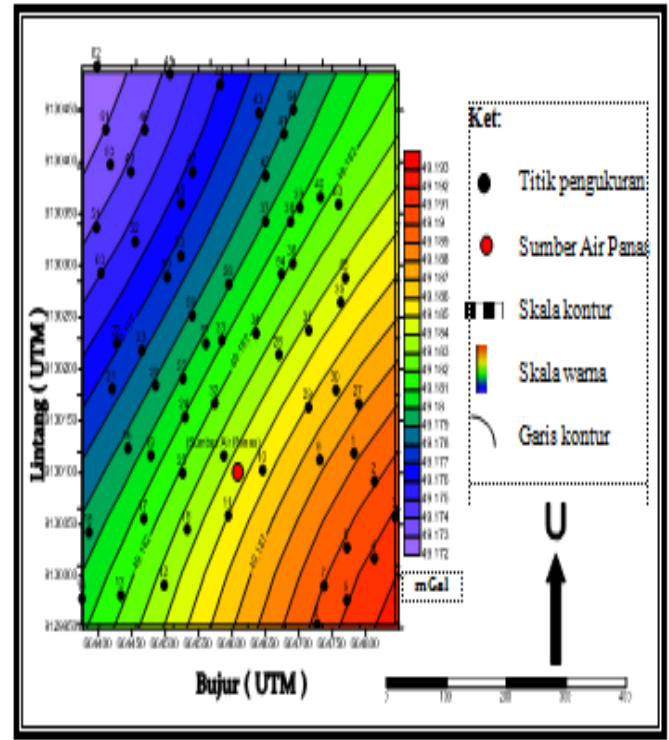

Gambar 4. Kontur anonali regional

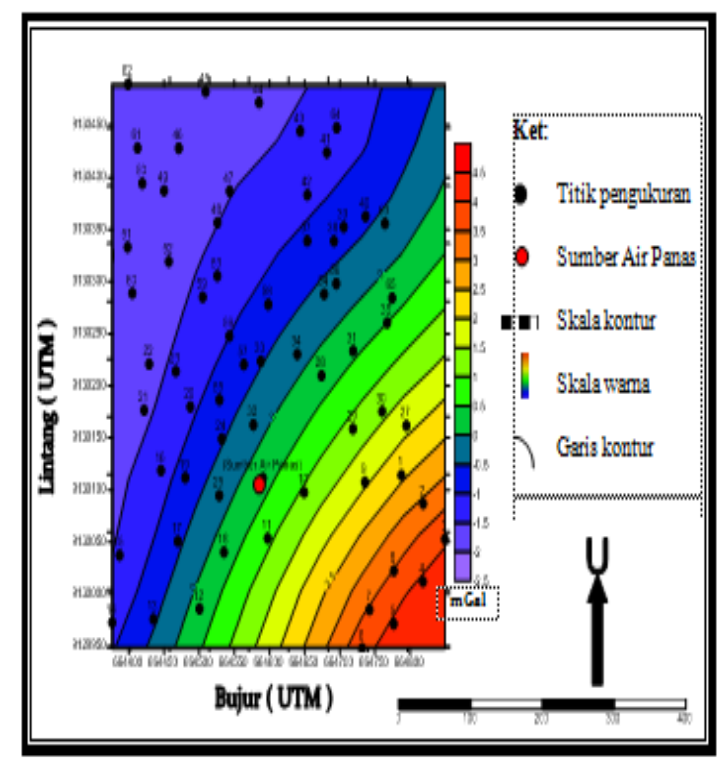

Gambar 5. Kontur anomali lokal

\section{Interpretasi Kuantitatif}

Interpretasi kuantitatif dilakukan dengan menganalisis penampang pola anomali sepanjang lintasan tertentu yang telah ditentukan. Dalam penelitian ini dibuat dua penampang anomali yaitu penampang $\mathrm{AB}$ (gambar 4) dan $\mathrm{CD}$ (gambar 6) pada kontur anomali lokal.

\section{Interpretasi Kuantitatif Anomali Lokal Penampang AB}

Penampang anomali Bouguer lokal lintasan AB diambil berdasarkan hasil penafsiran kualitatif pola kontur anomali, dimana pada penampang $\mathrm{AB}$ memotong beberapa tiggian dan rendahan anomali dengan nilai tertinggi $4.5 \mathrm{mGal}$ dan terendah -1.5 
mGal serta memotong sumber air panas yang berada pada titik 26. Lokasi penampang anomali Bouguer AB dapat dilihat pada gambar 6 berikut:

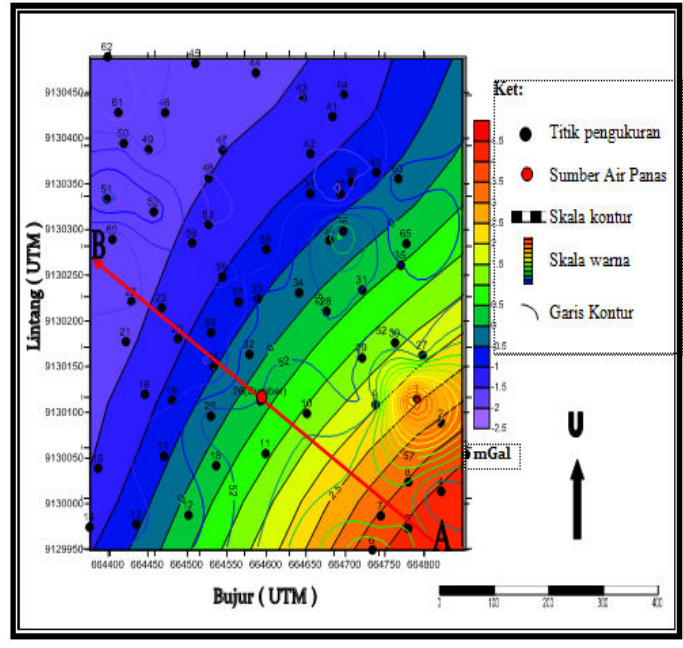

Gambar 6. Lintasan Penampang AB

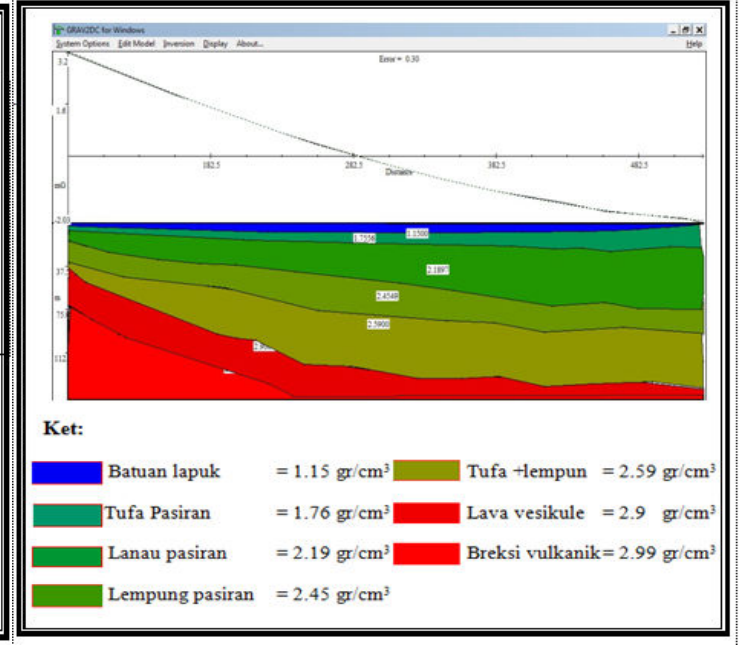

Gambar 7. Model penampang AB

Gambar 7 adalah gambar model penampang anomali lokal AB, pada sumbu Y pada area kurva adalah nilai anomali pengamatan (-1.96 - $3.2 \mathrm{mGal})$ sedangkan sumbu $\mathrm{X}$ merupakan nilai jarak lintasan (mencapai 532,5 m), sedangkan sumbu Y negatif pada area pemodelan adalah nilai kedalaman (mencapai $150 \mathrm{~m}$ ), garis putus-putus pada kurva adalah nilai anomali amatan sedangkan garis kontinu adalah anomali hasil perhitungan (respon dari pemodelan lapisan). Penafsiran litologi batuan pada daerah penelitian didasarkan pada data geologi. Berdasarkan informasi geologi diketahui bahwa daerah penelitian didominasi oleh batuan hasil erupsi gunungapi kuarter atas yaitu batuan yang dihasilkan oleh erupsi gunungapi Panderman (Qv-p) dan Penanggungan (Qv-n). Batuan hasil erupsi gunungapi kuarter atas berdasarkan peta geologi lembar Kediri terdiri dari breksi gunungapi, lava, tuf breksi tufaan, anglomerat. Selain itu penafsiran litologi batuan juga didasarkan hasil interpretasi penelitian sebelumnya oleh Priyambodo (2004) dengan metode resistivitas, bahwa struktur geologi daerah penelitian terdiri dari tujuh lapisan batuan (dapat dilihat dilampiran). Pada lapisan pertama dengan ditunjukkan dengan warna biru diduga sebagai batuan lapuk dengan nilai densitas $1.15 \mathrm{gr} / \mathrm{cm}^{3}$ yang merupakan hasil pelapukan dari air hujan dan akar tumbuhan, ketebalan lapisan ini bervariasi 1-3 m dari permukaan dengan sedangkan lapisan kedua ditunjukkan dengan hijau kelabu diduga sebagai tufa pasiran dengan nilai densitas $1.755 \mathrm{gr} / \mathrm{cm}^{3}$ pada kedalaman $5 \mathrm{~m}$ dengan ketebalan bervariasi dari 5-17 m, pada lapisan ketiga ditunjukkan dengan warna hijau diinterpretasi sebagai lanau pasiran dengan nilai densitas $2.189 \mathrm{gr} / \mathrm{cm}^{3}$ pada kedalaman $10 \mathrm{~m}$ dengan variasi ketebalan $8-50 \mathrm{~m}$. Lapisan ke empat di tunjukkan dengan warna hijau cerah ${ }_{3}$ diinterpretasikan sebagai batuan lempung pasiran dengan nilai densitas $2.45 \mathrm{gr} / \mathrm{cm}^{3}$ pada kedalaman $18 \mathrm{~m}$ dengan variasi ketebalan 9 - 16 m. Lapisan ke lima ditunjukkan dengan warna hijaukuning diinterpretasi sebagai breksi tufaan terlempungkan dengan nilai densitas $2.719 \mathrm{gr} / \mathrm{m}^{3}$ pada kedalaman $28 \mathrm{~m}$ dengan variasi ketebalan $9-50 \mathrm{~m}$. Lapisan keenam ditunjukkan dengan warna merah diinterpretasi sebagai batuan lava vulkanik Created with 
dengan nilai densitas $2.9 \mathrm{gr} / \mathrm{cm}^{3}$ pada kedalaman $37 \mathrm{~m}$ dengan variasi ketebalan 5 - $46 \mathrm{~m}$. Lapisan ke tujuh ditunjukkan dengan warna merah cerah _ diinterpretasikan sebagai batuan breksi vulkanik dengan nilai densitas $2,99 \mathrm{gr} / \mathrm{cm}^{3}$ pada kedalaman $75 \mathrm{~m}$ dengan ketebalan ratusan meter. Batuan ini diduga sebagai batuan sarang, sebagai tempat berkumpulnya fluida (air meteorik) yang telah terpanaskan oleh batuan pemanas, karena secara fisik batuan breksi vulkanik mempunyai sifat kesarangan yang baik. Selanjutnya batuan breksi tufaan terlempungkan pada lapisan ke lima diduga sebagai batuan penutup (cap rock), karena sifat impermeable dari lempung.

\section{Interpretasi Kuantitatif Penampang Anomali Lokal CD}

Penampang anomali lokal CD diambil berdasarkan hasil penafsiran kualitatif pola kontur anomali Bouguer, dimana pada penampang CD memotong beberapa tiggian dan rendahan anomali dengan nilai tertinggi $4.5 \mathrm{mGal}$ dan terendah $-1.5 \mathrm{mGal}$. Lokasi penampang anomali Bouguer CD dapat dilihat pada gambar berikut :

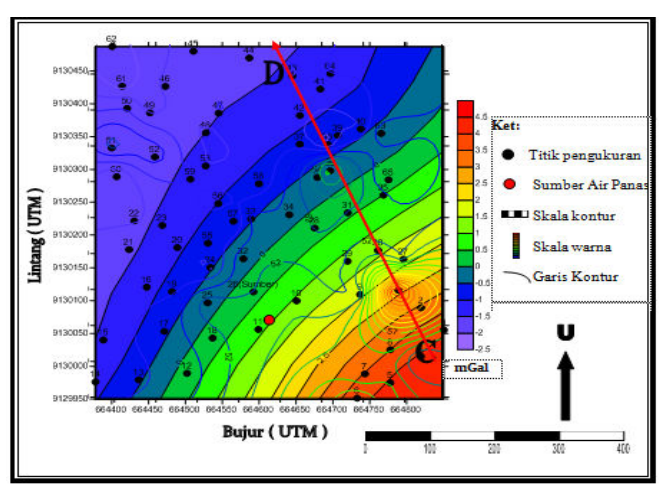

Gambar 8. Lintasan Penampang CD

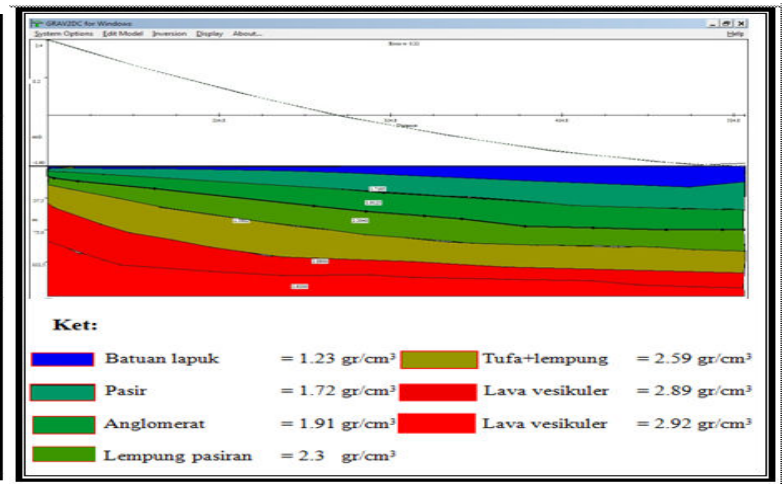

Gambar 9. Model Penampang CD

Gambar 9 adalah gambar model penampang anomali lokal CD, pada sumbu Y pada area kurva adalah nilai anomali pengamatan (-1.67 - $4.2 \mathrm{mGal})$ sedangkan sumbu $\mathrm{X}$ merupakan nilai jarak lintasan (mencapai $515 \mathrm{~m}$ ), sedangkan sumbu Y negatif pada area pemodelan adalah nilai kedalaman (mencapai $150 \mathrm{~m}$ ), garis putus-putus pada kurva adalah nilai anomali amatan sedangkan garis kontinu adalah anomali hasil perhitungan (respon dari pemodelan lapisan). Pada penampang lintasan CD pendugaan litologi batuan juga didasarkan pada salah satu titik pengamatan hasil interpretasi metode geolistrik yang telah dilakukan oleh Priyambodo (2004). Pada lapisan pertama ditunjukkan dengan warna biru diduga sebagai batuan lapuk dengan nilai densitas $1.23 \mathrm{gr} / \mathrm{m}^{3}$ yang merupakan hasil pelapukan dari air hujan dan akar tumbuhan, ketebalan lapisan ini bervariasi 1,2 - $15 \mathrm{~m}$ dari permukaan. Lapisan kedua ditunjukkan dengan hijau-kelabu diduga sebagai pasir berkerikil dengan nilai densitas $1.72 \mathrm{gr} / \mathrm{cm}^{3}$ pada kedalaman 1,2 $\mathrm{m}$ dengan ketebalan bervariasi dari 5 - $30 \mathrm{~m}$, pada lapisan ketiga ditunjukkan dengan warna hijau diinterpretasikan sebagai batuan anglomerat dengan nilai densitas $1.91 \mathrm{gr} / \mathrm{cm}^{3}$ pada kedalaman $6 \mathrm{~m}$ dengan variasi ketebalan 7 - $30 \mathrm{~m}$. Lapisan ke empat ditunjukkan dengan warna hijau cerah __ diinterpretasikan sebagai batuan lempung pasiran dengan nilai densitas $2.3 \mathrm{gr} / \mathrm{cm}^{3}$ pada kedalaman $13 \mathrm{~m}$ dengan variasi ketebalan 9 - 27 m. Lapisan ke lima ditunjukkan dengan warna hijau-kuning $\square$ diinterpretasi 
sebagai breksi tufaan terlempungkan dengan nilai densitas $2.59 \mathrm{gr} / \mathrm{m}^{3}$ pada kedalaman 22 $\mathrm{m}$ dengan variasi ketebalan 23 - $43 \mathrm{~m}$. Lapisan keenam ditunjukkan dengan warna merah diinterpretasi sebagai batuan lava vulkanik dengan nilai densitas $2.89 \mathrm{gr} / \mathrm{cm}^{3}$ pada kedalaman $43 \mathrm{~m}$ dengan variasi ketebalan 25 - $45 \mathrm{~m}$. Lapisan ke tujuh ditunjukkan dengan wanra merah cerah diinterpretasikan sebagai batuan lava vulkanik dengan nilai densitas $2,92 \mathrm{gr} / \mathrm{cm}^{3}$ pada kedalaman $85 \mathrm{~m}$ dengan variasi ketebalan 50 sampai $<100 \mathrm{~m}$. Penentuan nilai densitas baik pada model penampang AB maupun AC didasarkan pada nilai densitas yang sudah diketahui dari tabel pada dasar teori dan didasarkan pada teori bahwa semakin dalam nilai densitas batuan akan semakin besar.

\section{Analisis Potensi Geothermal}

Di daerah gunung api yang terdapat potensi geotermal banyak terdapat sesar akibat aktivitas tektonik, sesar-sesar tersebut akan mengakibatkan zona-zona rekahan yang menyebabkan air hujan akan menerobos masuk melalui rongga-rongga rekahan tersebut dan meuju lapisan yang lebih dalam sampai akhirnya bertemu dangan batuan panas. Air yang terakumulasi pada batuan panas tersebut lama kelamaan akan semakin panas kemudian sebagian berubah menjadi uap panas. Akibar perbedaan tekanan antara permukaan bumi dengan bawah pemukaan, maka air maupun uap panas akan berusaha mencari jalan keluar menuju permukaan bumi. Air atau uap panas yang muncul ke permukaan bumi tersebut dapat berupa uap panas, mata air panas maupun lumpur panas. Hal tersebut merupakan tanda-tanda adanya batuan terobosan yang memanaskan batuan tersebut dan merupakan potensi geothermal yang dapat dimanfaatkan sebagai sumber energi.

Berdasarkan interpretasi kualitatif pada kontur anomali Bouguer, anomali tinggi pada arah tenggara penelitian diduga sebagai lokasi batuan sumber pemanas pada sistem panasbumi di daerah Songgoriti. Anomali sedang yang berada pada arah timur laut daerah penelitian diduga berkorelasi dengan pola hidrothermal Cangar-Songgoriti-Kasinan yang berarah barat daya - timur laut. Adapun anomali rendah yang hampir 75\% mendominasi daerah penelitian diduga disebabkan oleh batuan vulkanik yang telah terubahkan, atau batuan vulkanik yang telah mengalami sedimentasi, hal ini didasarkan penelitian sebelumnya bahwa di daerah penelitian terdapat breksi, dan tuf yang terlempungkan.

Dari hasil interpretasi kuantitatif, pada penampang $\mathrm{AB}$ dan $\mathrm{AC}$, yang memotong anomali tinggian dan rendahan, didapatkan pada model penampang $\mathrm{AB}$ terlihat 7 lapisan yaitu: lapisan lapuk, tufa pasiran, lanau pasiran, lempung pasiran, tufa terlempungkan, lava vesikuler, breksi vulkanik. Sedangkan pada model penampang CD juga terdapat 7 lapisan yaitu : batuan lapuk, pasir, anglomerat, lempung pasiran, tufaan terlempungkan, lava vesikuer dan lava vesikuler.

Berdasarkan sifat fisik dari batuan pada lapisan-lapisan tersebut, batuan breksi gunungapi diduga sebagai batuan reservoir atau batuan sarang dalam sistem geothermal yang ada di sekitar Candi Songgoriti karena memiliki sifat kesarangan yang cukup baik. Sedangkan batuan penutup (cap rock) yang merupakan lapisan penahan fluida panas dari 
reservoir diperkirakan merupakan batuan tufaan yang terlempungkan, karena sifat impermeable dari batuan tersebut.

Interpretasi ini juga berdasarkan penelitian sebelumnya dengan metode geolistrik yang dilakukan oleh Priyambodo (2004) yang menyimpulkan bahwa batuan sarang pada sistem geothermal di daerah penelitian adalah batuan breksi terlempungkan dengan batuan sarang (reservoir) adalah batuan breksi vulkanik. Pada penelitian ini batuan pemanas pada sistem geothermal ini, belum bisa dipastikan, apakah berupa kantong magma atau berupa tubuh betuan beku yang besar, namun diduga kuat batuan tersebut berada pada daerah tenggara penelitian, hal ini didasarkan pada anomali tinggi di daerah tersebut. Untuk memastikan volume serta kepastian apakah berupa kantong magma atau tubuh batuan beku masih perlu penelitian lebih lanjut, dengan area penelitian yang lebih luas khususnya ke arah tenggara.

Menurut Sodakatu Taneda (Mardiana, 2007), lapangan panas bumi yang prospektif untuk dikembangkan adalah yang memiliki reservoir dengan temperatur yang tinggi (suhu minimal 1800C, lebih baik bila di atas 2000C), pada kedalaman kurang dari $3 \mathrm{~km}$ dari permukaan bumi, dengan volume reservoir yang permeable lebih dari $5 \mathrm{~km} 3$. Selain itu juga, adanya sesar yang dapat menjadi pathway pada caprock, untuk recharge air dari permukaan sampai kedalaman reservoir tersebut(5).

Pada penelitian ini tidak ditemukan sesar pada daerah penelitian, hal ini selaras dengan informasi yang terlihat pada peta geologi lembar Kediri, sehingga diduga kenampakan sistem geothermal yang ada, disebabkan oleh rekahan batuan atau rembesan.

Berdasarkan penelitian Hadisudewo D. (1982) penelitian geokimia daerah panasbumi Cangar-Padusan, G.Arjuno-Welirang-Anjasmoro, kabupaten Malang, Jawa Timur, Direktorat Vulkanologi, Bandung. Menyimpulkan bahwa Suhu air panas yang ada pada sumber air panas Songgoriti $47^{\circ} \mathrm{C}$, suhu udara $22^{\circ} \mathrm{C}$, terdapat oksida besi, luas kenampakan 4x4 m2, PH air netral (1).

Berdasarkan interpretasi kualitatif dan kuantitatif serta hasil penelitian sebelumnya maka dapat disimpulkan bahwa prospek atau potensi geothermal yang ada di wilayah Songgoriti untuk menjadi sumber alternatif, seperti pembangkit tenaga listrik sangat kecil. Namun, Kenampakan geothermal berupa air panas yang ada di sekitar Candi Songgoriti dapat dimanfaatkan dengan lebih kreatif lagi, karena potensi air panas (hidrothermal) pada daerah ini cukup besar, hal ini didasarkan pada interpretasi kuantitatif bahwa batuan reservoir (breksi vulkanik) sebagai penampug fluida panas, pada daerah Songgoriti diduga mempunyai ketebalan ratusan meter, pada kedalaman hal ini cukup baik untuk potensi air panas, didukung dengan sistem hidrologi bawah permukaan yang cukup baik.

Manifestasi geothermal berupa air panas di daerah Songgoriti dapat dimanfaatkan secara langsung sebagai berikut:

1. Pemandian air panas.

2. Pengeringan produk pertanian

3. Budidaya perikanan 
4. Pemanas ruangan

\section{KESIMPULAN}

Setelah dilakukan penelitian dengan metode gravitasi di sekitar sumber air panas daerah Songgoriti Kota Batu dapat disimpulkan bahwa:

1. Berdasarkan interpretasi kualitatif pola kontur anomali Bouguer dapat dibedakan menjadi 3 pola. Yaitu pola tinggian, pola sedang dan pola rendahan. Pola tinggian hanya berada pada arah tenggara penelitian dengan nilai anomali antara $58-67$ mGal. Pola anomali sedang terlihat pada daerah tenggara-selatan dengan nilai anomali 55 - $57 \mathrm{mGal}$ dan timur laut penelitian dengan nilai anomali 53 - 55 mGal. Sedangkan pola rendahan hampir $75 \%$ mendominasi daerah penelitian

2. Berdasarkan interpretasi kuantitatif pada model penampang lintasan $A B$, didapatkan tujuh lapisan batuan, yaitu batuan lapuk, tufa pasiran,lempung pasiran, breksi tufaan terlempungkan, lava, dan breksi vulkanik. Sedangkan model penampang lintasan AC juga didapatkan tujuh lapisan batuan, yaitu batuan lapuk, pasir, anglomerat, lempung pasiran, tufaan terlempungkan, lava vesikuer dan lava vesikuler. Karena batuan breksi vulkanik sangat baik dalam kesarangan, batuan ini diduga sebagai batuan sarang (penampung) fluida yang telah terpanaskan oleh batuan pemanas, dengan batuan breksi tufaan terlempungkan sebagai caprock (tudung) dari manifestasi sistem geothermal berupa air panas yang ada di sekitar Candi.

3. Berdasarkan interpretasi kualitatif dan kuantitatif serta penelitian sebelumnya, potensi geothermal di daerah songgoriti untuk menjadi sumber energi alternatif seperti pembangkit tenaga listrik sangat kecil.

\section{SARAN}

1. Bagi peneliti yang ingin melanjutkan penelitian ini disarankan untuk memperluas daerah penelitian khususnya ke arah tenggara daerah penelitian.

2. Dibutuhkan penelitian lebih lanjut baik dari bidang geofisika, geologi maupun geokimia, agar potensi geothermal bisa terpetakan dengan lebih rinci.

\section{DAFTAR PUSTAKA}

1.Anonymous.2011.http://volcanoindonesia.blogspot.com/2010/10/arjuno.html.Diakses tanggal 17 Juli 2011

2.Burger, H.Robert. 1992. Exploration Geophysics of the Shallow Subsurface. New Jersey: Prentice Hall

3.Blakely, Richard J.,1995. Potential Theory in Gravity and Magnetic Application. New York : Cambridge University Press 
4.Jacobs,J.A, Russel,R.D, Wilson,J.Tuzo. 1974. Physics and Geology. New York: Mc Graw-Hill Book Company

5.Nurlita, Ina.2010. Identifikasi Struktur Bawah Permukaan Dalam Hubungan Manifestasi Panas Bumi Berdasarkan Pemodelan 2-D Data Gayaberat Sepanjang Lintasan Pangalengan Garut. Tugasakhir. Bandung. FPMIPAUPI, http://repository. upi. edu/operator/upload/s_d0251_0608311_chapter4.pdf. Diakses tanggal 10 Juli 2011

6.Priyambodo, Bagus. 2004. Studi Zona Hidrotermal Songgoriti Batu dengan Metode Geolistrik Tahanan Jenis Konfigurasi Wenner Sounding. Tugas akhir Tidak Diterbitkan. Malang: Universitas Brawijaya Malang

7.Suharno. 2004. Pemanfaatan Energi Alternatif Panasbumi. Makalah Seminar Nasional. Bandar Lampung : Universitas Lampung.

8.Sunaryo.1997. Panduan Praktikum Geofisika. Universitas Brawijaya

9.Setyawan, Agus.2005.Kajian Metode Sumber Ekivalen Titik Massa Pada Proses Pengangkatan Data Gravitasi Ke Bidang datar. Laboratorium Geofisika, Jurusan Fisika Universitas Diponegoro, Berkala Fisika ISSN : 1410 - 9662. Vol.8, No.1.

10.Tim Pertamina. 2007. Peluang Pemanfaatan Potensi Energi Geothermal Ulubelu Lampung. Makalah Workshop. Bandar Lampung: Geofisika Universitas Lampung. 